\title{
LOCAL PUBLIC SERVICES AND MIGRATION: EDUCATIONAL CHANGE EVIDENCE FROM NORWEGIAN MUNICIPALITIES
}

\author{
Kjetil Andersson and Fredrik Carlsen ${ }^{*}$
}

\begin{abstract}
We take advantage of a large panel data base covering most Norwegian municipalities during seven years to examine the relationship between local public services and migration to and from municipalities for different age groups. The main innovation of the paper is that we use a survey data set to verify that the input measures employed as explanatory variables in the migration study actually are related to citizen satisfaction with local public services. We find that the results depend crucially on whether the input measures are instrumented. When input measures are instrumented, we find few effects of local public services on migration.
\end{abstract}

\section{INTRODUCTION}

A comprehensive theoretical literature discusses whether migration induced by local sector revenue and spending decisions is desirable. On one hand, migration makes communities more homogeneous. It can also dampen conflicts about local policy decisions as people move to communities where the local private/public spending mix and the mix between different categories of public spending suit their preferences [Tiebout (1956)]. Migration also represents a potential means by which voters can constrain monopoly bureaus and public sector unions from exploiting agenda control and bargaining power to drive up budgets and wages, and prevent elected officials from spending local resources to extend their power base and promote election prospects (Courant, Gramlich and Rubinfeld 1979, and Brennan and Buchanan 1980). On the other hand, migration may yield an inefficient allocation of national public spending, since movers ignore fiscal externalities imposed on origin and destination communities while local authorities ignore spillovers across jurisdiction borders when competing for jobs and wealthy taxpayers (Boadway and Flatters 1982, Brown and Oates 1987, and Taylor 1992).

Although the relationship between mobility and local government efficiency has been debated vigorously for almost four decades, we still have limited

\footnotetext{
Research Assistant and Associate Professor, Department of Economics, Norwegian University of Science and Technology. For helpful comments we are grateful to Søren Blomqvist, Lars-Erik Borge, Eiliv Jansen, Kåre Johansen, Karl Robertsen, Jørn Rattsø, three referees and seminar participants in Kristiansand, Saarbrücken and Trondheim. The research project has benefited from a grant by the Norwegian Research Council. The Norwegian Social Science Data Service (NSD) generously provided data. The usual caveats apply.
} 
knowledge about the extent to which location decisions are affected by local public services. For some categories of spending, like unemployment benefits and welfare assistance, empirical studies indicate that high benefit levels attract benefit recipients and deter other population groups [see, e.g., surveys by Cebula 1979. Moffit 1992 and Charney 1993). For other public sector services, like health care and education, conclusions are less clear-cut.

Most survey studies find that local public services matter in making location decisions. Three recent surveys of movers all concluded that $40-50$ percent of the respondents considered the quality of schools, parks and other local services to be important in choosing the community of residence (Percy and Hawkins 1992, Teske et al. 1993, and John et al. 1995). Sharp (1986) found that local public performance also serves as a 'push' factor. Of all respondents, 34 percent said they would definitely or probably exit if public services like garbage collection and police protection worsened, while 29 percent would exit if the quality of schools worsened. ${ }^{1}$

Although these studies indicate that people are concerned with the quality of local public services, we cannot conclude that migration is affected by decisions controlled by local authorities. Variations in quality may only be weakly related to variations in local input factors. For instance, most studies do not find school input measures, like expenditures per pupil or teacher/pupil ratios, to be important determinants of pupil achievement, drop-out rates or other output measures (Hanuschek 1986, and Hanuschek, Rivkin and Taylor 1995).

A number of studies have analyzed individual location choices or migration flows between jurisdictions using input measures like spending per capita/client as proxies for the quality of local public services (see surveys by Charney 1993 and Dowding, John and Biggs 1995). So far, no unambiguous conclusions have emerged from these studies. For instance, Herzog and Schlottmann (1986) and Fox et al. (1989) found that education expenditures reduce out-migration from U.S. metropolitan areas, while Knapp and White (1993) concluded that the rate of change rather than the level of education expenditures deter out-migration. Using an index for the supply of health care services based on physician density, hospital beds, etc., Porell (1982) found no effects on migration between U.S. metropolitan areas. In contrast, Day (1992) found that health expenditures affect migration between Canadian provinces.

In general, spending or other input measures are imperfect measures of the quality of local public services because quality also depends on a variety of demand and cost factors, like age structure, factor prices and scale effects. It is not inconceivable that spending and quality are negatively correlated; low education expenditures may reflect an area without serious social problems and low health expenditures may indicate that the population is comparatively healthy. Spending 
or other input measures are good proxies for quality only when the author(s) have controlled properly for variations in the relevant demand and cost factors.

The main innovation of this paper is that we use a survey data set to check that the input measures employed in the migration study actually reflect citizen satisfaction with local public services. The survey, which comprises 23,731 individuals, includes questions asking respondents to rank the quality of the main services provided by Norwegian municipalities. By matching each respondent with input variables for his/her municipality, we are able to examine how citizen satisfaction is related to municipal spending on the respective subservices or other variables characterizing the supply of municipal services.

When controlling for demand and cost factors, we find that our input measures are significant determinants of citizen satisfaction in four out of five subservices. ${ }^{2}$ Primary education is the odd man out; we find no relationship between school expenditures and citizen satisfaction with primary education services.

To examine the relationship between migration and the quality of local public services, as proxied by our input measures, we take advantage of a large panel data set covering most Norwegian municipalities during seven years. The data set allows us to address several methodological challenges facing research on migration between regions or municipalities.

First, as responses to public spending presumably vary between population groups, pooling different groups may conceal important effects. For this reason, we construct separate in- and out-migration rates for fine-grained age groups. We pool age groups which are relatively homogeneous in the sense that they benefit from the same municipal services.

Second, some studies-for example, Canadian studies of interprovincial migration-consider large geographical areas where the quality of public services is likely to be heterogeneous. Since most Norwegian municipalities are small, there is little intramunicipal variation in the quality of, and access to, local public services. Municipal averages of spending and other input measures are therefore likely to be relevant for individual migration decisions.

Third, researchers face a potential simultaneity problem, since local public spending decisions may depend on in- and out-migration. To check whether simultaneity may bias the results, we present GLS regressions and allow for the endogeneity of the regressors by using an instrumental variable procedure.

Our dependent variables are changes in the in- and out-migration rates, while the independent variables are changes in municipal input measures and other explanatory variables. By using differences, we control for time-invariant locationspecific amenities which cannot be observed or for which data are not available-for instance, aspects of the climate. Using differences also allows us to 
control for cross-section variations in demand and cost factors which pollute the relationship between input measures and quality. Since most relevant demand and cost factors, like the age structure or women's job participation rate, adjust slowly, changes in input measures will be a good approximation to changes in the quality of the respective services.

The rest of the paper is organized as follows. Section II describes the municipal sector in Norway and presents the data set used in the migration study. In section III, we employ the survey data set to check whether our input measures are related to citizen satisfaction with local public services. Section IV presents the results of the migration study, while section $\mathrm{V}$ offers concluding remarks.

\section{DATA DESCRIPTION}

Our main data source is the municipal data base gathered by the Norwegian Social Sciences Data Services (NSD). The data set consists of $\mathbf{4 1 2}$ Norwegian municipalities (out of a total of 435 in 1993) and covers seven years, from 1987 to 1993. We allow for inclusion of one lag of the explanatory variables; the estimation period is therefore 1988-1993. When an instrumental procedure is applied, the estimation period is 1989-1993, as variables dated two years before the observation and earlier are used as instruments.

In addition to variables related to each municipality's demography, labor market and local public services, the data base contains annual information for several age groups about the number of people who migrated to or from the municipality. The data base does not, however, show the identity of the origin and destination municipalities of each migrant.

The three main revenue sources of Norwegian municipalities are intergovernmental grants, local income taxes, and fees, which together account for 98 percent of local revenues. Both the local income tax rate and the tax base are regulated by the state. Therefore, all municipalities apply the same local income tax rate and tax base. Municipalities collect fees for some services, but fee income is not allowed to exceed production costs. The state also regulates the type of services for which municipalities may collect fees. As a consequence, municipalities have very little discretion to decide on revenues, leaving decisions on spending mix the main local policy issue.

The main services provided by the municipalities are day care services, primary education, cultural activities, primary health care, care for the elderly, and infrastructure. Good proxy variables for the quality of infrastructure services are not available; our study therefore comprises the first five municipal services. 
Separate migration analyses are conducted for age groups which we a priori expect to be homogeneous in the sense that they benefit from the same municipal services. Day care and primary education services are used by households with preschool and school children, respectively. As age is the only available personal characteristic of migrants, we use the migration rates of children aged 0-6 and 715 as proxies for the migration rates of households with preschool and school children, respectively.

The other age groups considered are 20-29 (which we expect to benefit from all services, but particularly from day care services); $30-49$ (expected to benefit from all services but particularly day care services and primary education); and 50-66 (expected to benefit from cultural activities, primary health care and possibly care for the elderly). We have not modelled migration of people older than 67 because of the very small migration rates of this group. School pupils aged 16 to 19 are excluded because municipalities are not responsible for providing secondary education.

Table 1 reveals large variations in average migration rates between the age groups. As expected, the migration propensity declines substantially with age for people above 20. This is also reflected in the difference between the migration rates of the age groups $0-6$ and 7-15. Notable is the low migration propensity of age group 7-15, probably reflecting that parents are reluctant to break up their children's social network once the children have reached school age.

Table 2 displays the correlation coefficients of the age groups' in-migration rates. Not surprisingly, migration rates for preschool children and people aged 20 29 and 30-49 are strongly (but not perfectly) correlated. The same holds for school pupils and people aged 30-49. The age group 50-66 exhibits a low correlation with the other age groups.

The descriptive statistics on migration rates from Tables 1 and 2 underline the importance of conducting separate migration analyses for the different age groups.

Variables employed to measure the quality of municipal services are listed in Table 1. Since the private supply of day-care services is low and the price charged by municipal centers is heavily subsidized, access to day-care services is in general, rationed. To capture potential migration responses to changes in the supply of day care services, it is thus necessary to obtain measures both related to the quality of day-care centers and to the likelihood of being admitted to a daycare center. We expect the quality of municipal day-care centers to be positively related to expenditures per child year, DAY_EXP. ${ }^{3}$ The coverage ratio, DAY_COV, is expected to be positively related to the likelihood of getting a place in a daycare center. 
TABLE 1

Variable Descriptions ${ }^{1}$

\begin{tabular}{|c|c|c|c|c|}
\hline Verible & & $\mathrm{Obs}^{2}$ & Mean & Std \\
\hline \multicolumn{5}{|c|}{ In-migration rates for age proups ${ }^{3}$} \\
\hline 0.6 & & 2884 & 0.064 & 0.029 \\
\hline $7-15$ & & 2884 & 0.023 & 0.013 \\
\hline $20-29$ & & 2884 & 0.102 & 0.038 \\
\hline $30-49^{\circ}$ & & 2884 & 0.033 & 0.013 \\
\hline $50-66$ & & 2884 & 0.012 & 0.008 \\
\hline \multicolumn{5}{|c|}{ Out-migration rates for age proups ${ }^{4}$} \\
\hline $0-6$ & & 2884 & 0.061 & 0.029 \\
\hline $7-15$ & & 2884 & 0.024 & 0.015 \\
\hline $20-29$ & & 2884 & 0.121 & 0.037 \\
\hline $30-49$ & & 2884 & 0.034 & 0.014 \\
\hline $50-66$ & & 2884 & 0.011 & 0.007 \\
\hline \multicolumn{5}{|c|}{ Lebor martet } \\
\hline COMINCOME & Average after-tax personal income in 10.000 NOK. & 2884 & 6.08 & 1.35 \\
\hline UNEMP & $\begin{array}{l}\text { Unemployment rate; Average number of unemployed } \\
\text { in year } t \text { divided by population betweeen } 15 \text { and } 67 . \\
\text { Data provided by Statistics Norway (SN). }\end{array}$ & 2884 & 0.03 & 0.014 \\
\hline \multicolumn{5}{|c|}{ Municipal envicess } \\
\hline DAY_EXP & $\begin{array}{l}\text { Current expenditures on day care services per } \\
\text { child year in municipal day care institutions. }\end{array}$ & 2884 & 5.68 & 2.66 \\
\hline DAY_COV & Percentage of children in day care institutions. & 2884 & 0.23 & 0.10 \\
\hline EDU_EXP & $\begin{array}{l}\text { Current expenditures on primary education } \\
\text { per pupil. }\end{array}$ & 2884 & 3.30 & 0.85 \\
\hline CUL_EXP & $\begin{array}{l}\text { Current expenditures on religious and cultural } \\
\text { activities per capita. }\end{array}$ & 2884 & 0.08 & 0.04 \\
\hline PHYS_COV & $\begin{array}{l}\text { Number of physician man-years in the primary } \\
\text { health care services per capita. Data provided by SN. }\end{array}$ & 2884 & 0.00079 & 0.00031 \\
\hline INST_EXP & $\begin{array}{l}\text { Current expenditures on nursing homes and other } \\
\text { institutions supplying care for the elderly per inhabitant } \\
67 \text { years of age and above. }\end{array}$ & 1895 & 2.22 & 1.11 \\
\hline HOME_EXP & $\begin{array}{l}\text { Current expenditures on the supply of home-based } \\
\text { care per inhabitant } 67 \text { years and above. }\end{array}$ & 1895 & 1.01 & 1.24 \\
\hline
\end{tabular}

Notes:

1. All data are from the Norwegian Social Science Data Service (NSD) if not otherwise noted.

2. Summary statistics are calculated on the panel dataset comprising 412 municipalities during the period 1987 1993, except for the variables INST_EXP and HOME_EXP, where 379 municipalities during the period 1989.

1993 are used due to missing data.

3. The in-migration rates are defined as the number of immigrants in the age group in year $t$ divided by the number of people in the age group living in the receiving municipality at date 1.1 in year $t$.

4. The out-migration rates is defined as the number of emigrants in the age group in year $t$ divided by the number of people in the age group living in the sending municipality at date 1.1 in year t.

5. All expenditure measures are in 10.000 Norwegian kroner, 1987 prices. The demographic variable in the denominator of the municipal services measures is always dated 1.1. 
TABLE 2

Correlation Matrix for In-migration Rates 1

\begin{tabular}{lllll}
\hline \hline & $0-6$ & $7-15$ & $20-29$ & $30-49$ \\
\hline $7-15$ & 0.50 & & & \\
$20-29$ & 0.59 & 0.38 & & \\
$30-49$ & 0.64 & 0.66 & 0.60 & \\
$50-66$ & 0.26 & 0.27 & 0.36 & 0.37 \\
\hline
\end{tabular}

Notes:

1. See table 1 for variable definition. Number of observations is 2884 .

Municipalities are responsible for providing compulsory primary education to children aged 7 to 15 years. Primary education services are not rationed. Any incentives to relocate must therefore be due to variations in the quality of schools. As proxy for quality, we use expenditures per pupil, EDU_EXP. ${ }^{4}$

For cultural activities, only information about total expenditures are available. Our proxy for quality is therefore expenditures on cultural activities per capita, CUL_EXP.

Primary health care consists mainly of consultations provided by general practitioners. Municipal spending data are not relevant for our purpose because some, but not all, general practitioners receive fees from the state; variations in municipal expenditures on primary health care therefore reflect variations in the share of fee-for-service physicians. As input measure, we therefore use physician density, PHYS_COV, set equal to the number of general practitioners per capita.

Municipalities provide two types of community care: nursing home services and home care for people who cannot live in their own houses. Both services are used primarily by elderly people. As access to community care services is rationed in some municipalities, using coverage ratios as input measures would be preferable. However, only expenditure data are available; our proxies for quality are therefore expenditures on home care services, HOME_EXP, and expenditures on nursing homes, INST_EXP, both scaled by the population above $66^{5}$

Two variables are included to capture migration incentives arising from variations in local labour market conditions; the municipality's unemployment rate, UNEM, and the municipality's average post-tax personal income, COMINCOME. ${ }^{6}$ Both variables are scaled by the respective national averages. Since all regressions are estimated in differences, the included explanatory variables are change in relative unemployment rate and change in relative income. The survey analysis presented in the next section confirms that the municipality's unemployment rate and average income are related to people's perception of the local job 
situation. We have also considered a third candidate, employment growth, but this variable did not perform as well as the others in the survey analysis.

\section{A CHECK ON THE INPUT MEASURES}

To check whether our input measures reflect people's perception of the quality of local services, we employ a survey data set gathered by the Norwegian Gallup Institute (NGI). During 1993 and 1994, NGI mailed a questionnaire to a random sample of about 33.600 persons. ${ }^{7}$ Respondents were asked to rank municipal services, including the five services covered by our study, on a discretionary scale from 1 to 6 , where 1 is 'very dissatisfied' and 6 is 'very satisfied.' Respondents were also asked to rank the local job situation using the same scale.

Follow-up contacts produced a final sample of 23.731 individuals from 427 municipalities. We merged the NGI and NSD data sets by matching each respondent with input variables dated 1993 for his/her municipality.

As is evident from Table 3, only a minority of the respondents ranked the quality of primary education. This probably reflects a low response rate in households without school pupils. ${ }^{8}$ People tend to be relatively satisfied with schools and primary health care and less satisfied with the supply of cultural activities and care for the elderly.

In all satisfaction regressions, we include five personal characteristics taken from the questionnaire: age, income, and dummies for sex, college degree and marital status. We also include a set of demographic variables to control for variations across municipalities in demand and cost factors.

The municipality's average personal income and education level, COMINCOME and COMEDU, are expected to affect the demand for all services, particularly day care services and cultural activities. The number of welfare recipients per capita, WELFARE, and the unemployment rate, UNEM, are included as proxies for the degree of social problems, which may influence the demand for all municipal services.

Women's job participation rate, FEMPAR, is expected to affect the demand for day care services, care for the elderly and possibly also primary health care. The population share above 66, POP67+/POP, may affect the demand for all services while the share of elderly people above 79 , POP80+/POP67+, is expected to affect the demand for primary health care and care for the elderly. To capture scale effects in the production of municipal services, we include population size, POP, and a measure of population density, DISTANCE.?

Ordered probit regressions are displayed in Table $4 .{ }^{10}$ In the first column, satisfaction with the local job market is the dependent variable. For both variables 
TABLE 3

Description of Variables Employed in Analysis of Satisfaction

\begin{tabular}{|c|c|c|c|c|}
\hline Variable $^{1}$ & & $\mathrm{~N}$ & Mean & Std \\
\hline \multicolumn{5}{|c|}{ Satisfaction indices ${ }^{2}$} \\
\hline EMPLOYMENT & $\begin{array}{l}\text { Degree of satisfaction with the job market } \\
\text { in the municipality. }\end{array}$ & 16885 & 2.80 & 1.46 \\
\hline DAYCARE & $\begin{array}{l}\text { Degree of satisfaction with the supply of } \\
\text { day care services in the municipality. }\end{array}$ & 14478 & 4.12 & 1.36 \\
\hline SCHOOLS & $\begin{array}{l}\text { Degree of satisfaction with the municipal } \\
\text { supply of primary education services. }\end{array}$ & 6513 & 4.61 & 1.19 \\
\hline CULTURE & $\begin{array}{l}\text { Degree of satisfaction with the supply of } \\
\text { cultural services in the municipality. }\end{array}$ & 17868 & 3.99 & 1.31 \\
\hline PHYSSERV & $\begin{array}{l}\text { Degree of satisfaction with primary health } \\
\text { care services in the municipality. }\end{array}$ & 18740 & 4.62 & 1.29 \\
\hline OLDCARE & $\begin{array}{l}\text { Degree of entisfaction with the municipal } \\
\text { supply of care for the elderly. } \\
\text { Pereonil Chriacteristics }\end{array}$ & 15095 & 3.67 & 1.39 \\
\hline AGE & Age of the respondent. & 23728 & 42.26 & 15.90 \\
\hline MARRIED & Binary variable, 1 if married, 0 otherwise ${ }^{3}$. & 19531 & 0.67 & 0.46 \\
\hline MALE & Binary variable, 1 if respondent is male, 0 otherwise. & 23731 & 0.49 & 0.50 \\
\hline INCOME & Household-income of the respondent, in 100.000 NOK. 2 & 20441 & 3.03 & 1.97 \\
\hline COLLEGE & $\begin{array}{l}\text { Binary variable, } 1 \text { if respondent has a } \\
\text { university or college degrec, } 0 \text { otherwice. } \\
\text { Muaicipal Cherecteristics }\end{array}$ & 23708 & 0.22 & 0.41 \\
\hline POP & Number of citizens in the municipality. & 412 & 8575.5 & 15789 \\
\hline DISTANCE & $\begin{array}{l}\text { A verage travel time (in minutes) to the } \\
\text { municipality center. Source: Statistics Norway (SN). }\end{array}$ & 412 & 13.91 & 11.02 \\
\hline WELFARE & Number of people on welfare-payments per capita. & 412 & 0.03 & 0.01 \\
\hline FEMPART & $\begin{array}{l}\text { Female participation rate. Number of women } \\
\text { working more than } 1000 \text { hours per year divided } \\
\text { by number of women } 16-66 \text { years (1990). Source: SN }\end{array}$ & 412 & 0.31 & 0.06 \\
\hline COMEDU & Percentage of population with higher education, (1990). & 412 & 0.09 & 0.03 \\
\hline $\begin{array}{l}\text { POP67+/POP } \\
\text { POP80+/POP67+ }\end{array}$ & $\begin{array}{l}\text { Share of population } 67 \text { years and above. } \\
\text { Number of people } 80 \text { years and above divided } \\
\text { by number of people } 67 \text { years and above. }\end{array}$ & $\begin{array}{l}412 \\
412\end{array}$ & $\begin{array}{l}0.16 \\
0.27\end{array}$ & $\begin{array}{l}0.04 \\
0.04\end{array}$ \\
\hline COMINCOME & Average after-tax personal income in 10.000 NOK (1992). & 412 & 7.39 & 1.73 \\
\hline UNEMP & $\begin{array}{l}\text { Unemployment rate; Average number of unemployed } \\
\text { in year } t \text { divided by number of people between } 15 \\
\text { and } 67 \text {. Source: SN. }\end{array}$ & 412 & 0.04 & 0.012 \\
\hline \multicolumn{5}{|c|}{ Municipal Services } \\
\hline DAY_EXP & $\begin{array}{l}\text { Current expenditures on day care services per } \\
\text { child year in municipal day care institutions. }\end{array}$ & 412 & 7.49 & 2.93 \\
\hline DAY_COV & Percentage of children in day care institutions. & 412 & 0.31 & 0.10 \\
\hline EDU_EXP & Current expenditures on primary education per pupil. & 412 & 4.25 & 1.09 \\
\hline CUL_EXP & $\begin{array}{l}\text { Current expenditures on religious and cultural } \\
\text { activities per capita. }\end{array}$ & 412 & 0.11 & 0.05 \\
\hline PHYS_COV & $\begin{array}{l}\text { Number of physician man-years in the primary } \\
\text { health care service per capita. Source:SN. }\end{array}$ & 412 & 0.00086 & 0.00033 \\
\hline INST_EXP & $\begin{array}{l}\text { Current expenditures on nursing homes and other } \\
\text { institutions supplying care for the elderly per inhabitant } \\
67 \text { years of age and above. }\end{array}$ & 379 & 2.46 & 10.21 \\
\hline HOME_EXP & $\begin{array}{l}\text { Current expenditures on the supply of home-based } \\
\text { care per inhabitant } 67 \text { years and soove. }\end{array}$ & 379 & 1.35 & 9.80 \\
\hline
\end{tabular}

Notes:

1. The summary statistics of personal characteristics and the satisfaction indices are calculated after removal of individuals that have not answered the question, or explicitly answered "don't know." All survey variables are from the Norwegian Gallup Institute. The survey set was gathered during 1993 and 1994.

2. Response on a discretionary scale from 1 to 6 , where 1 is "very dissatisfied," and 6 is "very satisfied."

3. Married also includes couples living together.

4. Municipal characteristics and municipal input measures are provided by The Norwegian Social Science Data Service (NSD) and dated 1993 if not otherwise mentioned. Expenditure measures are in 10.000 current NOK. 
TABLE 4

Determinants of Citizen Satisfaction

\begin{tabular}{|c|c|c|c|c|c|c|}
\hline & $\begin{array}{c}\text { Employ- } \\
\text { ment }\end{array}$ & Day care & $\begin{array}{c}\text { Primary } \\
\text { eduction }\end{array}$ & Culture & $\begin{array}{c}\text { Physician } \\
\text { services }\end{array}$ & $\begin{array}{l}\text { Care for the } \\
\text { elderly }\end{array}$ \\
\hline AGE & $\begin{array}{r}0.0020 \\
(2.52)\end{array}$ & $\begin{array}{l}0.0142 \\
(15.70)\end{array}$ & $\begin{array}{r}0.0020 \\
(1.00)\end{array}$ & $\begin{array}{l}0.0147 \\
(19.08)\end{array}$ & $\begin{array}{l}0.0169 \\
(19.62)\end{array}$ & $\begin{array}{r}0.0055 \\
(6.29)\end{array}$ \\
\hline MALE & $\begin{array}{r}0.0218 \\
(1.13)\end{array}$ & $\begin{array}{r}-0.0138 \\
(-0.66)\end{array}$ & $\begin{array}{r}-0.1916 \\
(-5.70)\end{array}$ & $\begin{array}{r}-0.1802 \\
(-9.63)\end{array}$ & $\begin{array}{l}-0.2304 \\
(-11.19)\end{array}$ & $\begin{array}{r}0.09470 \\
(4.43)\end{array}$ \\
\hline Log(INCOME) & $\begin{array}{r}0.1898 \\
(6.34)\end{array}$ & $\begin{array}{r}0.0133 \\
(0.39)\end{array}$ & $\begin{array}{r}-0.1296 \\
(-2.24)\end{array}$ & $\begin{array}{r}-0.0050 \\
(-0.16)\end{array}$ & $\begin{array}{r}-0.0404 \\
(-1.21)\end{array}$ & $\begin{array}{r}0.0477 \\
(1.43)\end{array}$ \\
\hline COLLEGE & $\begin{array}{l}0.3509 \\
(15.55)\end{array}$ & $\begin{array}{r}-0.0954 \\
(-3.81)\end{array}$ & $\begin{array}{r}-0.0513 \\
(-1.27)\end{array}$ & $\begin{array}{r}0.0331 \\
(1.48)\end{array}$ & $\begin{array}{r}-0.1173 \\
(-4.66)\end{array}$ & $\begin{array}{r}0.0999 \\
(3.79)\end{array}$ \\
\hline MARRIED & $\begin{array}{r}-0.0626 \\
(-2.58)\end{array}$ & $\begin{array}{r}-0.0140 \\
(-0.50)\end{array}$ & $\begin{array}{r}0.1680 \\
(3.12)\end{array}$ & $\begin{array}{r}0.0673 \\
(2.83)\end{array}$ & $\begin{array}{r}0.0109 \\
(0.40)\end{array}$ & $\begin{array}{r}-0.0003 \\
(-0.01)\end{array}$ \\
\hline $\log (P O P)$ & $\begin{array}{r}0.0048 \\
(0.30)\end{array}$ & $\begin{array}{r}-0.2108 \\
(-11.12)\end{array}$ & $\begin{array}{r}-0.0521 \\
(-1.50)\end{array}$ & $\begin{array}{l}0.1858 \\
(11.60)\end{array}$ & $\begin{array}{r}0.1470 \\
(7.96)\end{array}$ & $\begin{array}{r}-0.3027 \\
(-15.22)\end{array}$ \\
\hline Log(DISTANCE) & $\begin{array}{r}0.0955 \\
(5.09)\end{array}$ & $\begin{array}{r}-0.1068 \\
(-4.73)\end{array}$ & $\begin{array}{r}-0.0197 \\
(-0.52)\end{array}$ & $\begin{array}{r}-0.1458 \\
(-7.67)\end{array}$ & $\begin{array}{r}-0.1347 \\
(-6.32)\end{array}$ & $\begin{array}{r}-0.1239 \\
(-5.62)\end{array}$ \\
\hline WELFARE & $\begin{array}{r}-5.9379 \\
(-5.90)\end{array}$ & $\begin{array}{r}-4.959 \\
(-4.42)\end{array}$ & $\begin{array}{r}-1.4626 \\
(-0.80)\end{array}$ & $\begin{array}{r}-1.9302 \\
(-1.92)\end{array}$ & $\begin{array}{r}-2.4062 \\
(-2.13)\end{array}$ & $\begin{array}{r}-8.8683 \\
(-7.76)\end{array}$ \\
\hline FEMPART & $\begin{array}{r}0.7988 \\
(4.27)\end{array}$ & $\begin{array}{r}-1.1395 \\
(-4.90)\end{array}$ & $\begin{array}{r}-0.6340 \\
(-1.91)\end{array}$ & $\begin{array}{r}-0.4129 \\
(-2.24)\end{array}$ & $\begin{array}{c}-1.3118 \\
(-6.55)\end{array}$ & $\begin{array}{r}-0.9116 \\
(-4.44)\end{array}$ \\
\hline COMEDUC & $\begin{array}{r}-0.3161 \\
(-0.66)\end{array}$ & $\begin{array}{r}-1.4350 \\
(-2.74)\end{array}$ & $\begin{array}{r}1.8108 \\
(2.27)\end{array}$ & $\begin{array}{r}2.6524 \\
(5.88)\end{array}$ & $\begin{array}{r}0.6010 \\
(1.21)\end{array}$ & $\begin{array}{r}2.2277 \\
(4.38)\end{array}$ \\
\hline POP67+/POP & $\begin{array}{r}-0.5918 \\
(-1.60)\end{array}$ & $\begin{array}{r}1.5286 \\
(3.61)\end{array}$ & $\begin{array}{r}1.1612 \\
(1.73)\end{array}$ & $\begin{array}{r}0.7524 \\
(2.06)\end{array}$ & $\begin{array}{r}-0.3674 \\
(-0.91)\end{array}$ & $\begin{array}{r}0.1519 \\
(0.34)\end{array}$ \\
\hline POP80+/POP67+ & $\begin{array}{r}1.6571 \\
(4.78)\end{array}$ & $\begin{array}{r}0.5898 \\
(1.57)\end{array}$ & $\begin{array}{r}-0.6047 \\
(-0.98)\end{array}$ & $\begin{array}{r}0.5270 \\
(1.55)\end{array}$ & $\begin{array}{r}0.0999 \\
(0.26)\end{array}$ & $\begin{array}{r}-1.2791 \\
(-3.20)\end{array}$ \\
\hline COMINCOME & $\begin{array}{r}0.1076 \\
(9.05)\end{array}$ & $\begin{array}{c}-0.0308 \\
(-2.25)\end{array}$ & $\begin{array}{r}-0.0091 \\
(-0.41)\end{array}$ & $\begin{array}{r}-0.0469 \\
(-3.91)\end{array}$ & $\begin{array}{r}-0.0353 \\
(-2.73)\end{array}$ & $\begin{array}{r}-0.0238 \\
(-1.77)\end{array}$ \\
\hline UNEMP & $\begin{array}{l}-12.004 \\
(-13.55)\end{array}$ & $\begin{array}{r}-1.1417 \\
(-1.13)\end{array}$ & $\begin{array}{r}-1.0729 \\
(-0.65)\end{array}$ & $\begin{array}{r}-4.6520 \\
(-5.26)\end{array}$ & $\begin{array}{r}-0.1391 \\
(-0.14)\end{array}$ & $\begin{array}{r}-1.1335 \\
(-1.10)\end{array}$ \\
\hline DAY_EXP & & $\begin{array}{r}0.0264 \\
(4.21)\end{array}$ & & & & \\
\hline DAY_COV & & $\begin{array}{l}2.1723 \\
(14.57)\end{array}$ & & & & \\
\hline EDU_EXP & & & $\begin{array}{r}-0.0068 \\
(-0.21)\end{array}$ & & & \\
\hline CUL_EXP & & & & $\begin{array}{r}2.6969 \\
(11.82)\end{array}$ & & \\
\hline PHYS_COV & & & & & $\begin{array}{r}341.36 \\
(6.36)\end{array}$ & \\
\hline INST_EXP & & & & & & $\begin{array}{r}0.0472 \\
(3.32)\end{array}$ \\
\hline HOME_EXP & & & . & & & $\begin{array}{r}0.0520 \\
(3.61)\end{array}$ \\
\hline $\mathbf{M U}(2)$ & $\begin{array}{l}0.5892 \\
(54.73)\end{array}$ & $\begin{array}{l}0.5913 \\
(31.59)\end{array}$ & $\begin{array}{l}0.5056 \\
(13.09)\end{array}$ & $\begin{array}{l}0.6646 \\
(35.26)\end{array}$ & $\begin{array}{r}0.4587 \\
(21.91)\end{array}$ & $\begin{array}{l}0.6535 \\
(38.89)\end{array}$ \\
\hline $\operatorname{MU}(3)$ & $\begin{array}{l}1.2551 \\
(88.54)\end{array}$ & $\begin{array}{l}1.2761 \\
(57.95)\end{array}$ & $\begin{array}{l}1.0891 \\
(24.36)\end{array}$ & $\begin{array}{r}1.4660 \\
(67.59)\end{array}$ & $\begin{array}{l}1.0990 \\
(43.94)\end{array}$ & $\begin{array}{l}1.3362 \\
(67.35)\end{array}$ \\
\hline MU(4) & $\begin{array}{r}1.8727 \\
(108.19)\end{array}$ & $\begin{array}{r}2.0374 \\
(85.86)\end{array}$ & $\begin{array}{l}1.8550 \\
(39.39)\end{array}$ & $\begin{array}{r}2.2444 \\
(97.31)\end{array}$ & $\begin{array}{l}1.8035 \\
(68.24)\end{array}$ & $\begin{array}{l}2.1075 \\
(95.10)\end{array}$ \\
\hline MU(5) & $\begin{array}{r}2.4004 \\
(113.59)\end{array}$ & $\begin{array}{r}2.8905 \\
(111.74)\end{array}$ & $\begin{array}{r}2.7807 \\
(56.61)\end{array}$ & $\begin{array}{r}3.0229 \\
(121.30)\end{array}$ & $\begin{array}{r}2.6285 \\
(94.79)\end{array}$ & $\begin{array}{r}2.9634 \\
(113.59)\end{array}$ \\
\hline Log-L & -20070.80 & -16227.86 & -6240.07 & -20322.23 & -16529.29 & -15888.14 \\
\hline $\mathbf{N}$ & 12254 & 10354 & 4218 & 12776 & 11008 & 9750 \\
\hline
\end{tabular}

Notes:

1. Ordered probit estimates, asymptotic $t-v a l u e s$ in parentheses.

2. Log- $\mathrm{L}$ is $\log$ of the likelihood function, $N$ is number of observations. The MUOs are the estimated th reshold levels, MU(1) is set to 0 . 
employed in the migration study, the municipality's unemployment rate, UNEM, and average personal income, COMINCOME, the coefficients have the expected sign and are highly significant.

The other columns show the estimated regressions where satisfaction with municipal services is the dependent variable. With the exception of care for the elderly, the personal characteristics variables exhibit a consistent pattern; older people, women, and people without a college degree are generally more satisfied with municipal services than young people, men, and people with a college degree. ${ }^{11}$ Most coefficients of the demographic variables have the expected sign; for instance, the women's job participation rate has a negative impact on satisfaction with day care services, and the number of welfare recipients per capita has a negative impact on satisfaction with primary health care.

Our proxies for quality have the expected effect on citizen satisfaction in four out of five sectors. Both expenditures per child year and the coverage ratio have a positive impact on satisfaction with day care services, and the coefficients are very significant. Expenditures on cultural activities are positively related to satisfaction with cultural services. Physician density is a significant determinant of satisfaction with primary health care, and municipal spending on home care and nursing homes are significant determinants of satisfaction with care for the elderly.

Primary education is the odd man out; neither expenditures per pupil nor the alternative input measures we have employed (regressions not reported) affect satisfaction with schools.

The results indicate that our input measures are sensible proxies for the quality of local public services, with primary education being the only exception. Furthermore, the analysis underscores the importance of controlling for variations in demand and cost factors when spending or other input variables are used to explain migration; for all services, most demographic variables included are significant determinants of citizen satisfaction. ${ }^{12}$

\section{RESULTS}

Municipal input measures may be endogenous to migration as local authorities may respond to population changes. To check whether simultaneity represents a problem, we present both robust GLS estimates and estimates using an instrumental variable (IV) approach. Our choice of IV estimator is the generalized method of moments (GMM) estimator suggested by Arellano and Bond (1991). This estimator uses lags of variables as instruments in an efficient way. ${ }^{13}$ 
In the reported regressions, the municipal input measures are scaled by the national averages (constructed by assigning equal weights to all municipalities) in the respective years. The in-migration (out-migration) rate of an age group is scaled by the age group's population in the destination (origin) municipality at the beginning of the year. An alternative would be to scale by the total population of the destination (origin) municipality. The two alternatives give virtually identical results.

To wipe out the effects of time invariant location specific amenities, the equations are estimated in first differences. This procedure also controls for crosssection variation in demographic variables reflecting demand and cost factors. Demographic variables cannot be included as regressors when we use first differences, as they change very slowly over time.

Time dummies are included in all regressions to capture labour market variations at the national level as well as variations in other relevant macrovariables. Wald tests suggest that the time dummies are jointly significant.

In preliminary regressions, we included both lagged and current values of the explanatory variables as well as one lag of the dependent variable as regressors. To save space, we report only regressions including current values; the coefficients of lagged variables were in general insignificant, and when they were significant, the implied long-term elasticities of the municipal input measures were very similar to the elasticities implied by the reported regressions.

Pairwise comparisons show that the explanatory. variables are only weakly correlated. We therefore present regressions where all explanatory variables are included simultaneously.

Table 5 reports estimation results for in-migration rates using the whole sample. The coefficient of the municipal unemployment rate always has the expected negative sign and is significant for most age groups. The coefficient of municipal average personal income is insignificant for all age groups except people aged 50-66, for which the coefficient has the 'wrong' sign. One possible explanation is that personal income also serves as a proxy for the demand for local public services, as suggested by the analysis of citizen satisfaction reported in section III.

Turning to the municipal input measures, we consider first the GLS estimates. With the exception of physician density and spending on nursing homes, the coefficients of all input measures are significant and have the expected sign for one or more age groups; both day care measures have a positive and significant impact on in-migration of households with preschool children; expenditures per pupil have a significant impact on in-migration of households with school pupils and people aged 30-49; and spending on home care services has a significant impact on in-migration of people aged 50-66. Households with school 
pupils are also attracted by spending on cultural activities. The Wald test suggests that the municipal input measures are jointly significant for all age groups except people aged 20-29.

With the exception of expenditures per pupil, the implied elasticities are modest. A 1 percent increase in day-care coverage (spending per-child year) raises the in-migration rate of preschool children with 0.21 percent $(0,08$ percent); a 1 percent increase in spending on cultural activities raises the in-migration rate of school pupils with 0,19 percent; and a 1 percent percentage increase in spending on home-based care raises the in-migration rate of people aged 50-66 with 0,05 percent.

The implied elasticity of the in-migration rate of school pupils with respect to expenditures per pupil is as high as 2.02 . This result seems implausible, given that we were not able to detect any relationship between citizen satisfaction with the quality of schools and expenditures per pupil.

The GMM estimates give a very different picture: Compared to the GLS estimates, all significant coefficients become insignificant, and all but one significant coefficient (of EDU_EXP for people aged 30-49) are reduced in absolute value. This suggests that the GLS estimates, at least to some extent, reflect reverse causality; municipalities spend more on day care services when households with preschool children immigrate; more on primary education and cultural services when households with school pupils immigrate; and more on home-based services when older people immigrate.

An alternative explanation for the different GLS and GMM estimates is that the instruments applied by the GMM estimator are of poor quality, i.e., they are only weakly correlated with the explanatory variables. To examine this possibility in more detail, we have conducted regressions (not reported) where both the municipal input measures and the local unemployment rate are instrumented. The quality of the two sets of instruments should be roughly equal as the correlations between changes in input measures and the instruments (two and more lags of the input level) are comparable to the correlations between change in unemployment and the instruments. ${ }^{14}$ It turns out that the estimated coefficient of the local unemployment rate is not substantially affected when the variable is instrumented (if anything, the absolute value and t-statistics increase). We consider this result to be evidence against the alternative explanation.

It can be argued that local public services are more likely to influence mobility in densely populated areas than in rural regions largely consisting of unconnected villages. We have reestimated all regressions (not reported) for a subsample consisting of 87 municipalities located within the commuting areas of the 11 largest Norwegian cities. Compared to the results reported in Table 5, the 
TABLE 5

In-migration Determinants

\begin{tabular}{|c|c|c|c|c|c|c|}
\hline \multirow{2}{*}{$\begin{array}{l}\text { Age group: } \\
\text { Eetimmution } \\
\text { method: }\end{array}$} & \multicolumn{2}{|l|}{$0-6$} & \multicolumn{2}{|c|}{$7-15$} & \multicolumn{2}{|c|}{$20-29$} \\
\hline & GLS & GMM & GLS & GMM & GLS & GMM \\
\hline COMINCOME & 0.03452 & \multirow{8}{*}{$\begin{array}{r}0.00955 \\
(0.23) \\
-0.01222 \\
(-2.01) \\
0.00069 \\
(0.15) \\
0.00195 \\
(0.26) \\
0.00068 \\
(0.01) \\
-0.01018 \\
(-1.15) \\
-0.00244 \\
(-0.22)\end{array}$} & -0.00165 & -0.00503 & -0.03480 & -0.04056 \\
\hline UNEMP & $\begin{array}{r}(0.77) \\
-0.00849\end{array}$ & & $\begin{array}{c}-(.0 .08) \\
-0.00072\end{array}$ & $\begin{array}{r}(-0.22) \\
-0.00226\end{array}$ & $\begin{array}{r}(-0.92) \\
-0.00582\end{array}$ & $\begin{array}{r}(-1.09) \\
-0.00897\end{array}$ \\
\hline DAY_EXP & $\begin{array}{l}(-1.98) \\
0.00497\end{array}$ & & $\begin{array}{l}(-0.44) \\
0.00039\end{array}$ & $\begin{array}{l}(-0.98) \\
0.00398\end{array}$ & 0.00212 & $\begin{array}{l}(-2.23) \\
0.00396\end{array}$ \\
\hline DAY COV & $\begin{array}{r}(2.60) \\
0.01368\end{array}$ & & $\begin{array}{r}(0.42) \\
-0.0228\end{array}$ & $\begin{array}{r}(1.75) \\
-0.00197\end{array}$ & 0.0338 & $(1.02)$ \\
\hline DAY_COV & $\begin{array}{l}0.01368 \\
(2.68)\end{array}$ & & $(-0.83)$ & $(-0.58)$ & $\begin{array}{l}0.00338 \\
(0.72)\end{array}$ & $0.0 .23)$ \\
\hline EDU_EXP & $\begin{array}{r}-0.01905 \\
(-1.21)\end{array}$ & & $\begin{array}{r}0.04666 \\
(4.60)\end{array}$ & $\begin{array}{r}0.03288 \\
(1.43)\end{array}$ & $\begin{array}{r}0.00530 \\
(0.38)\end{array}$ & $\begin{array}{r}0.00182 \\
(0.04)\end{array}$ \\
\hline CUL_EXP & 0.00250 & & 0.00439 & -0.00067 & -0.00166 & -0.00860 \\
\hline PHY_COV & $\begin{array}{r}-0.00494 \\
(-1.29)\end{array}$ & & $\begin{array}{r}-0.00258 \\
(-1.87)\end{array}$ & $\begin{array}{r}(-0.14) \\
-0.00953 \\
(-1.59)\end{array}$ & $\begin{array}{r}0.00175 \\
(0.64)\end{array}$ & $\begin{array}{r}0.01376 \\
(1.32)\end{array}$ \\
\hline $\begin{array}{l}\text { Diagnostics: } \\
\text { Obs } \\
\text { m2 } \\
\text { Wald } \\
\text { Sargan }\end{array}$ & $\begin{array}{l}2472 \\
0.739 \\
15.07(5)\end{array}$ & $\begin{array}{l}2060 \\
1.301 \\
1.82(5) \\
78.00(70)\end{array}$ & $\begin{array}{c}2472 \\
-1.097 \\
34.18(5)\end{array}$ & $\begin{array}{r}2060 \\
-1.285 \\
8.16(5) \\
83.66(70)\end{array}$ & $\begin{array}{r}2472 \\
-0.453 \\
2.92 \text { (5) }\end{array}$ & $\begin{array}{c}2060 \\
-0.455 \\
4.92(5) \\
73.86(70)\end{array}$ \\
\hline \multirow{2}{*}{$\begin{array}{l}\text { Age group: } \\
\text { Estimption } \\
\text { method }\end{array}$} & \multicolumn{3}{|c|}{$30-49$} & \multicolumn{2}{|c|}{$50-66$} & \\
\hline & \multicolumn{2}{|l|}{ GLS } & & GLS & \multicolumn{2}{|c|}{ GMM } \\
\hline COMINCOME & \multirow{10}{*}{$\begin{array}{r}-0.01014 \\
(-0.85) \\
-0.00214 \\
(-1.71) \\
0.00040 \\
(0.70) \\
0.00098 \\
(0.50) \\
0.01171 \\
(2.31) \\
0.00343 \\
(1.59) \\
-0.00174 \\
(-1.43)\end{array}$} & \multirow{10}{*}{\multicolumn{2}{|c|}{$\begin{array}{r}-0.01073 \\
(-0.73) \\
-0.00394 \\
-(-2.37) \\
-0.00031 \\
(-0.20) \\
0.00185 \\
(0.56) \\
0.02319 \\
(1.29) \\
-0.00491 \\
-(-1.47) \\
-0.00784 \\
(-1.77)\end{array}$}} & -0.03325 & \multirow{10}{*}{\multicolumn{2}{|c|}{$\begin{array}{r}-0.03334 \\
(-2.75) \\
-0.00180 \\
(-1.13) \\
-0.00107 \\
(-0.54) \\
0.00102 \\
(0.28) \\
-0.02364 \\
(-1.43) \\
-0.00384 \\
(-1.11) \\
-0.00009 \\
(-0.01) \\
-0.00051 \\
(-0.26) \\
-0.00034 \\
(-0.42)\end{array}$}} \\
\hline UNEMP & & & & -0.00203 & & \\
\hline DAY_EXP & & & & 0.00090 & & \\
\hline DAY_COV & & & & 0.00333 & & \\
\hline EDU_EXP & & & & 0.00219 & & \\
\hline CUL_EXP. & & & & $\begin{array}{r}(0.42) \\
-0.00006\end{array}$ & & \\
\hline CUL_EAT? & & & & $(-0.04)$ & & \\
\hline PHY_COV & & & & $\begin{array}{c}0.00082 \\
(0.58)\end{array}$ & & \\
\hline INST_EXP & & & & -0.00052 & & \\
\hline HOME_EXP & & & & $\begin{array}{r}0.00063 \\
(6.89)\end{array}$ & & \\
\hline $\begin{array}{l}\text { Diagnostics: } \\
\text { Obs } \\
\text { mald }^{2} \\
\text { Salden }\end{array}$ & $\begin{array}{r}2472 \\
-0.891 \\
11.58(5)\end{array}$ & \multicolumn{2}{|c|}{$\begin{array}{c}2060 \\
-0.921 \\
6.12 \\
85.38(70)\end{array}$} & $\begin{array}{r}1516 \\
0.441 \\
110.50(7)\end{array}$ & \multicolumn{2}{|c|}{$\begin{array}{c}1137 \\
0.601 \\
6.44 \\
39.82(35)\end{array}$} \\
\hline
\end{tabular}

Notes:

1. Equations are estimated in first differences; right-hand side variables are divided by sample year mean; and time dummies are included in all equations (not reported).

2. Asymptotic t-statistics are reported below the coefficients. All test statistics are robust to general cross-section and time-series heteroskedasticity, and are one-step if not otherwise mentioned. See Arellano and Bond (1991). 3. $\mathrm{m} 2$ is a test for second-order serial correlation in the residuals, asymptotically distributed as $\mathrm{N}(0,1)$ under the null of no serial correlation.

4. Sargan (two-step) is a test of the overidentifying restrictions, asymptotically distributed as chi-square under the null of instrumental validity. Degrees of freedom are in parentheses. Instruments are defined in the text.

5. Wald is a test of joint significance of the municipal services measures, asymptotically distributed as chi-square under the null of no relationship. Degrees of freedom are in parenthesis. 
estimated standard errors are generally higher, but none of the major conclusions is affected.

Table 6 reports regression results for out-migration using the whole sample. ${ }^{15}$ The in-migration rate of the previous year is included as the explanatory variable because a municipality with a high proportion of recent immigrants may have a high out-migration rate due to the high migration propensity of prior migrants. See e.g. Nelson and Wyzan (1989).

Neither of our local labour market variables achieves significance for any age group; i.e., local unemployment affects in-migration but not out-migration. For primary education and home-based services, the GLS results are quite similar to the results of the in-migration study: an increase in expenditures per pupil is associated with lower out-migration rates of households with school pupils, while an increase in spending on home-based care is associated with lower out-migration of people aged 50-66. As for in-migration, the former elasticity is high (1.54) while the latter is small (0.03). We find also an effect of expenditures per pupil on in-migration of households with preschool children. The coefficients of the day care, culture, primary health care and nursing home variables are insignificant in every regression.

Compared to the GLS estimates, the GMM estimates indicate that spending on home-based care has no effect on migration, while the results for primary education become stronger; for children below 16 , the coefficients are increasing (absolute value); and expenditures per pupil also become significant for the age group 30-49. The GMM estimates give two counterintuitive results; higher spending on day care dampens out-migration of people aged 50-66 and encourages outmigration of people aged 20-29. We have not been able to find any plausible explanation for these results.

\section{v. CONCLUSION}

In this paper, we have tried to address several methodological challenges facing research on Tiebout mobility: 1) migration rates are computed for age groups which are relatively homogeneous in the sense that they benefit from the same municipal services; 2) the analysis is based on a geographical unit (the municipality) for which there is little internal variation in the quality of local public services; and 3) a survey data set is used to check that the municipal input measures employed as explanatory variables in the migration regressions are related to people's evaluation of the quality of local public services.

Our main conclusion is that the results depend crucially on whether we use an instrumental variable approach. The robust GLS estimates suggest that most 
TABLE 6

Out-migration Determinants

\begin{tabular}{|c|c|c|c|c|c|c|}
\hline \multirow{2}{*}{$\begin{array}{l}\text { Ase group: } \\
\text { Bstimation } \\
\text { method: }\end{array}$} & \multicolumn{2}{|l|}{$0-6$} & \multicolumn{2}{|c|}{$7-15$} & \multicolumn{2}{|c|}{$20-29$} \\
\hline & GLS & GMM & GLS & GMM & GLS & GMM \\
\hline lag(INMIGR) & 0.04036 & \multirow{2}{*}{$\begin{array}{r}0.05792 \\
(1.70) \\
-0.02042\end{array}$} & 0.03225 & 0.00820 & 0.05244 & 0.03891 \\
\hline COMINCOME & $\begin{array}{r}(1.17) \\
-0.01344\end{array}$ & & $\begin{array}{l}(0.72) \\
0.01721\end{array}$ & $\begin{array}{l}(0.16) \\
0.02181\end{array}$ & $\begin{array}{l}(1.65) \\
0.04799\end{array}$ & 0.05325 \\
\hline UNEMP & $\begin{array}{r}(-0.31) \\
-0.00167\end{array}$ & $\begin{array}{r}(-0.50) \\
-0.00146\end{array}$ & $\begin{array}{r}(0.96) \\
-0.00119\end{array}$ & $\begin{array}{r}(1.10) \\
-0.00168\end{array}$ & $\begin{array}{r}(1.58) \\
-0.00067\end{array}$ & $\begin{array}{l}0.67) \\
0.00074\end{array}$ \\
\hline DAY_EXP & $\begin{array}{r}(-0.41) \\
0.00091\end{array}$ & \multirow{2}{*}{$\begin{array}{r}0.00661 \\
(1.39)\end{array}$} & $\begin{array}{r}(-0.65) \\
-0.00150\end{array}$ & $\begin{array}{l}(-0.91) \\
0.00168\end{array}$ & $(-0.19)$ & $\begin{array}{l}(0.20) \\
0.00122\end{array}$ \\
\hline DAY COV & $(0.54)$ & & $(-1.65)$ & (0.62) & (0.74) & $(0.28)$ \\
\hline DAY_COV & $\begin{array}{r}-0.00366 \\
(-0.58)\end{array}$ & $\begin{array}{r}0.00164 \\
(0.21)\end{array}$ & $\begin{array}{l}-0.00177 \\
(-0.56)\end{array}$ & $\begin{array}{r}-0.00219 \\
(-0.43)\end{array}$ & $\begin{array}{r}0.00338 \\
(0.73)\end{array}$ & $\begin{array}{r}0.02405 \\
(2.64)\end{array}$ \\
\hline EDU_EXP & $\begin{array}{r}-0.03675 \\
(-2.30)\end{array}$ & $\begin{array}{r}-0.08742 \\
(-2.16)\end{array}$ & $\begin{array}{l}-0.03733 \\
(-5.20)\end{array}$ & $\begin{array}{r}-0.06649 \\
(-2.46)\end{array}$ & $\begin{array}{l}-0.01308 \\
(-1.11)\end{array}$ & $\begin{array}{l}0.04771 \\
(1.34)\end{array}$ \\
\hline CUL_EXP & 0.00701 & $\begin{array}{r}0.00187 \\
(0.24)\end{array}$ & 0.00106 & -0.00679 & 0.00411 & -0.00336 \\
\hline PHY_COV & 0.00146 & $\begin{array}{r}-0.00332 \\
(-0.29)\end{array}$ & -0.00066 & -0.00571 & $\begin{array}{l}-0.00078 \\
-0.72)\end{array}$ & 0.00875 \\
\hline \multicolumn{7}{|l|}{ Diagnostics: } \\
\hline $\begin{array}{l}\text { Obs } \\
\text { m1 } \\
\text { m2 } \\
\text { Wald } \\
\text { Sargan }\end{array}$ & $\begin{array}{c}2060 \\
-7.893 \\
0.738 \\
7.40(5)\end{array}$ & $\begin{array}{l}2060 \\
-7.992 \\
0.903 \\
5.96(5) \\
68.41(70)\end{array}$ & $\begin{array}{r}2060 \\
-7.142 \\
-0.306 \\
33.52(5)\end{array}$ & $\begin{array}{r}2060 \\
-6.641 \\
-0.167 \\
8.81(5) \\
64.92(70)\end{array}$ & $\begin{array}{r}2060 \\
-6.105 \\
0.934 \\
2.78(5)\end{array}$ & $\begin{array}{r}2060 \\
-5.984 \\
0.614 \\
8.59(5) \\
6.93(70)\end{array}$ \\
\hline \multirow{2}{*}{$\begin{array}{l}\text { Age group: } \\
\text { Ectimintion } \\
\text { method: }\end{array}$} & \multicolumn{3}{|c|}{$30-49$} & \multicolumn{3}{|c|}{$50-66$} \\
\hline & \multicolumn{2}{|l|}{ GLS } & GMM & GLS & \multicolumn{2}{|c|}{ GMM } \\
\hline Lag(INMIGR) & \multirow{12}{*}{$\begin{array}{r}0.02050 \\
(0.62) \\
-0.00791 \\
(-0.55) \\
0.00127 \\
(0.77) \\
-0.00096 \\
(-1.20) \\
-0.00049 \\
(-0.20) \\
-0.00192 \\
(-0.31) \\
0.00056 \\
(0.33) \\
0.00048 \\
(0.33)\end{array}$} & \multirow{12}{*}{\multicolumn{2}{|c|}{$\begin{array}{r}0.00106 \\
(0.03) \\
-0.00126 \\
(-0.08) \\
0.00072 \\
(0.38) \\
0.00044 \\
(0.23) \\
0.00492 \\
(1.18) \\
-0.04825 \\
(-2.61) \\
-0.00684 \\
(-1.46) \\
-0.00000 \\
(-0.00)\end{array}$}} & 0.06775 & \multirow{12}{*}{\multicolumn{2}{|c|}{$\begin{array}{r}0.05424 \\
(0.98) \\
-0.00243 \\
(-0.20) \\
0.00012 \\
(0.06) \\
-0.00323 \\
(-2.23) \\
-0.00461 \\
(-1.24) \\
0.01773 \\
(1.25) \\
-0.00343 \\
(-1.10) \\
0.00409 \\
(0.78) \\
0.00298 \\
(1.66) \\
-0.00052 \\
(-0.89)\end{array}$}} \\
\hline COMINCOME & & & & -0.00633 & & \\
\hline UNEMP & & & & $\begin{array}{r}(-0.58) \\
-0.00015\end{array}$ & & \\
\hline DAY_EXP & & & & $\begin{array}{r}(-0.09) \\
-0.00065\end{array}$ & & \\
\hline DAY_COV & & & & $\begin{array}{l}(-0.90) \\
0.00244\end{array}$ & & \\
\hline EDU_EXP & & & & $\begin{array}{l}(1.41) \\
0.00023\end{array}$ & & \\
\hline CUL EXP & & & & $\begin{array}{r}(0.05) \\
-0.00098\end{array}$ & & \\
\hline CUL_EX & & & & $(-0.51)$ & & \\
\hline PHY_COV & & & & -0.00084 & & \\
\hline INST_EXP & & & & 0.00070 & & \\
\hline HOME_EXP & & & & -0.00035 & & \\
\hline \multicolumn{2}{|l|}{ Diagnostics: } & & & & & \\
\hline $\begin{array}{l}\text { Obs } \\
\mathrm{m1} \\
\mathrm{m} 2 \\
\text { Wald } 1 \\
\text { Sarean }\end{array}$ & \multicolumn{2}{|c|}{$\begin{array}{r}2060 \\
-7.012 \\
-0.560 \\
1.73(5)\end{array}$} & $\begin{array}{r}2060 \\
-6.440 \\
-0.335 \\
9.43(5) \\
63.321(70)\end{array}$ & $\begin{array}{l}1137 \\
-7.204 \\
0.802 \\
20.27 \text { (7) }\end{array}$ & \multicolumn{2}{|c|}{$\begin{array}{l}1137 \\
-6.632 \\
0.563 \\
18.16(7) \\
40.08(35)\end{array}$} \\
\hline
\end{tabular}

Notes:

1. Equations are estimated in first differences; right-hand side variables are divided by sample year mean; and time dummies are included in all equations (not reported).

2. Asymptotic t-statistics are reported below the coefficients. All test statistics are robust to general cross-section and time-series heteroskedasticity, and one-step if not otherwise mentioned. See Arellano and Bond (1991).

3. $\mathrm{m} 2$ is a test for second order serial correlation in the residuals, asymptotically distributed as $N(0,1)$ under the null of no serial correlation.

4. Sargan (two-step) is a test of the overidentifying restrictions, asymptotically distributed as chi-square under the null of instrumental validity. Degrees of freedom are in parentheses. Instruments are defined in the text.

5. Wald is a test of joint significance of the municipal services measures, asymptotically distributed as chi-square under the null of no relationship. Degrees of freedom are in parenthesis. 
local public services affect migration (particularly in-migration), while we find few effects of local public services on migration when input measures are instrumented. This suggests that simultaneity is a potential problem in studies of Tiebout mobility; migration decisions may be affected by local public services, while local spending decisions may be affected by population changes.

We obtain the strongest results for primary education. Expenditures per pupil seem to be a significant determinant of out-migration of children below 16 and people aged 30-49. This result is a puzzle, as the survey data analysis did not detect any relationship between expenditures per pupil and citizen satisfaction with the quality of schools.

\section{ENDNOTES}

1. Somewhat weaker results are reported in Lowery and Lyons (1989). Among residents in ten Kentucky counties, $0.8-1.6 \%$ said they planned to leave as a result of anything pertaining to local government performance.

2. Day care services, cultural services, primary health care and care for the elderly.

3. Child year is somewhat lower than the number of slots, since some centers provide part-time services. DAY_EXP refers to municipal day care centers, as spending data for private suppliers are not available.

4. Using the teacher/pupil ratio or pupilteacher ratio as explanatory variables in the in- and out-migration regressions produces very similar results.

5. Community care variables are available from 1989. Compared to the other regressions, the estimation period is therefore two years shorter when HOME_EXP and INST_EXP are included as regressors.

6. Unemployment benefits are standardized by the national government and do not vary across municipalities.

7. Small (large) municipalities were slightly overrepresented (underrepresented) in order to obtain responses from as many municipalities as possible.

8. Data about the number and age of children in the respondent's household are not available. Therefore, we cannot conduct separate analyses for families with school children.

9. DISTANCE is the population's average travelling time to the municipality center.

10. If residuals across people from the same municipality are correlated, the reported t-values may be biased upwards [Moulton (1990)].

11. Interestingly, econometric studies of job satisfaction give very similar results: older workers, women and workers with a low level of education tend to 
be more satisfied with their job situations than younger workers, men and workers with a high level of education (Clarke, 1995).

12. Again, primary education is an exception.

13. As instruments we use all municial input measures (in levels) lagged two years and more. The two-test statistics of instrumental validity ( $\mathrm{m}_{2}$ and Sargan) are below critical values at the 5 percent level of confidence for all regressions reported.

14. The correlation between change in local unemployment and two lags of local unemployment is $-0,29$ while the correlations between change in municipal input measures and two lags of the input level are in the area of -0.08 to -0.27 .

15. As for in-migration, the standard errors increase when we consider only municipalities within commuting areas, and most coefficients become insignificant.

\section{REFERENCES}

Arellano, Manuel, and Stephen Bond. "Some Tests of Specification for Panel Data: Monte Carlo Evidence and an Application to Employment Equations." Review of Economic Studies 58 (1991): 277-297.

Boadway, Robin, and Frank Flatters. "Efficiency and Equalization Payments in a Federal System of Government: A Synthesis and Extension of Recent Results." Canadian Journal of Economics 15 (1982): 613-633.

Brennan, Geoffrey, and James Buchanan. The Power to Tax: Analytical Foundations of a Fiscal Constitution. Cambridge, Cambridge University Press, 1980.

Brown, Charles C., and Wallace E. Oates. "Assistance to the Poor in a Federal System." Journal of Public Economics 32 (1987): 307-330.

Cebula, Richard J. "A Survey of the Literature on the Migration-Impact of State and Local Government Policies." Public Finance 34 (1979): 69-84.

Charney, Alberta H. "Migration and the Public Sector: A Survey." Regional Studies 27 (1993): 313-326.

Clark, Andrew E. "Is Utility Relative? Evidence from Household Data." Working Paper, DELTA, Paris, 1995.

Courant, Paul N., Edward M. Gramlich, and Daniel Rubinfeld. "Public Employee Market Power and the Level of Government Spending." American Economic Review 69 (1979): 806-817.

Day, Kathleen M. "Interprovincial Migration and Local Public Goods." Canadian Journal of Economics 25 (1992): 123-144. 
Dowding, Keith, Peter John, and Stephen Biggs. "Tiebout: A Survey of the Empirical Literature." Urban Studies 31 (1994): 767-797.

Fox, William F., Henry W. Herzog, and Alan M. Schlottman. "Metropolitan Fiscal Structure and Migration." Journal of Regional Science 29 (1989): 523536.

Hanuschek, Eric A. "The Economics of Schooling: Production and Efficiency in Public Schools." Journal of Economic Literature 24 (1986): 1141-1177.

Hanuschek, Erik A., Stephen G. Rivkin, and Lori L. Taylor. "The Identification of School Resource Effects." Paper presented at the NSF/Review of Economics and Statistics on School Quality and Educational Outcomes, Harvard 1994.

Herzog, Henry W., and Alan M. Schlottmann. "State and Local Tax Deductibility and Metropolitan Migration." National Tax Journal 39 (1986): 189-200.

John, Peter, Keith Dowding, and Stephen Biggs. "Residential Mobility in London: A Micro-Level Test of the Behavioural Assumptions of the Tiebout Model." British Journal of Political Science 25 (1995): 379-397.

Knapp, Thomas A., and Nancy E. White. "Migration Decisions and Site-Specific Attributes of Public Policy: Microeconomic Evidence from the NLSY." Review of Regional Studies 23 (1993): 169-184.

Lowery, David, and William E. Lyons. "The Impact of Jurisdictional Boundaries: An Individual-Level Test of the Tiebout Model." Journal of Politics 51 (1989): 73-97.

Moffitt, Robert. "Incentive Effects of the U.S. Welfare System: A Review." Journal of Economic Literature 30 (1992): 1-62.

Moulton, Brent R. "An Illustration of a Pitfall in Estimating the Effects of Aggregate Variables on Micro Units." Review of Economics and Statistics (1990): 334-338.

Nelson, Michael A., and Michael L. Wyzan. "Public Policy, Local Labor Demand, and Migration in Sweden, 1979-84." Journal of Regional Science 29 (1989): 247-264.

Percy, Stephen, and Brett Hawkins. "Further Tests of Individual-level Propositions from the Tiebout Model." Journal of Politics 54 (1992): 1149-1157.

Porell, Frank W. "Intermetropolitan Migration and Quality of Life." Journal of Regional Science 22 (1982): 137-158.

Sharp, Elaine B. Citizen Demand-Making in the Urban Context, Alabama, The University of Alabama Press, 1986.

Shaw, Paul R. "Fiscal versus Traditional Market Variables in Canadian Migration." Journal of Political Economy 94 (1986): 648-666.

Taylor, Leon. "Infrastructural Competition among Jurisdictions." Journal of Public Economics 49 (1992): 241-259. 
Teske, Paul, Mark Schneider, Michael Mintrom, and Samuel Best. "Establishing the Micro Foundations of a Macro Theory: Information, Movers, and the Competitive Local Market for Public Goods." American Political Science Review 87 (1993): 702-713.

Tiebout, Charles M. "A Pure Theory of Local Expenditures." Journal of Political Economy 64 (1956): 416-424. 